\title{
Minimally Invasive Interventions Used with the Guidance of SPECT/CT in the Treatment of Mediastinal Parathyroid Adenomas
}

\author{
Mediastinal Paratiroid Adenomlarının Tedavisinde SPECT/BT Rehberliğinde Uygulanan Minimal \\ İnvazif Girişimler
}

\author{
Oya YILDIZ1 \\ (i) 0000-0002-1051-3470 \\ Alper FINDIKÇIOĞLU ${ }^{1}$ \\ (D) 0000-0001-8740-163X \\ Dalokay KILIÇ ${ }^{2}$ \\ (D) 0000-0001-7813-5317 \\ Neşe TORUN ${ }^{3}$ \\ (1D) 0000-0002-5597-676X
}

\begin{abstract}
Locating and removing ectopic parathyroid tissue may result in more than $20 \%$ failure. Seven cases which were detected by single photon emission computed tomography/computed tomography (SPECT/CT) imaging with Tc-99m sestamibi and treated with minimally invasive surgical methods were presented. The cases that underwent SPECT/CT due to high parathormone $(\mathrm{PTH})$ level after total/subtotal parathyroidectomy operation, and detected to have mediastinal ectopic parathyroid were included. The success of the surgery was assessed with preoperative and postoperative PTH levels. Video-assisted thoracic surgery (VATS) was performed on five of the cases and video-assisted mediastinoscopy (VAM) was performed on remaining two. The mean age was $52.4 \pm 19.0$. There were six women and one man. Mediastinal adenomas ranging from 1.5 to $6 \mathrm{~cm}$ in size, were successfully treated after single attempt. If the mediastinal ectopic parathyroid adenomas are fully localized before surgery, it can be treated with minimally invasive surgical methods.
\end{abstract}

Keywords: Ectopic parathyroid; parathormone; single photon emission computed tomography.

\section{ÖZ}

Ektopik paratiroid dokusunun yerini saptamak ve çıkarmak \%20'nin üzerinde başarısızlıkla sonuçlanabilmektedir. Tc-99m sestamibi ile yapılan tek foton emisyon bilgisayarlı tomografi/bilgisayarlı tomografi (single photon emission computed tomography/computed tomography, SPECT/CT) görüntülemesinde saptanan ve minimal invaziv cerrahi yöntemler ile tedavi edilen yedi olgu sunulmuştur. Total/subtotal paratiroidektomi operasyonu sonrası yüksek parathormon (PTH) seviyesi nedeni ile SPECT/CT uygulanan ve mediastende ektopik paratiroid saptanan olgular dahil edilmiştir. Cerrahinin başarısı preoperatif ve postoperatif PTH düzeyleri ile değerlendirildi. Beş olguya video yardımlı toraks cerrahisi (video-assisted thoracic surgery, VATS), diğer ikisine video yardımlı mediastinoskopi (video-assisted

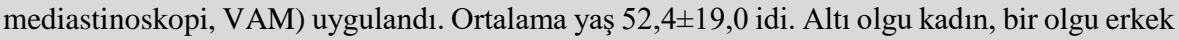
idi. 1,5 ile $6 \mathrm{~cm}$ arasında değişen mediastinal adenomlar tek denemeden sonra basit girişimler ile başarılı bir şekilde tedavi edildi. Mediastinal ektopik paratiroid adenomu ameliyat öncesi tam olarak lokalize edilebilirse minimal invaziv cerrahi yöntemlerle tedavi edilebilir.

Anahtar kelimeler: Ektopik paratiroid; parathormon; tek foton emisyon bilgisayarlı tomografi.

\section{INTRODUCTION}

Primary hyperparathyroidism (HPT) is a disease characterized by hypercalcaemia, hypophosphatemia and excessive bone resorption resulting from excessive parathormone $(\mathrm{PTH})$ release from the parathyroid gland. The cause is parathyroid adenomas in $85 \%$ of patients, parathyroid hyperplasia in $15 \%$ and more rarely parathyroid carcinoma in $1-2 \%$. Treatment of parathyroid adenoma is surgical (1). Ectopic parathyroid tissue is a rare entity that causes severe metabolic problems (2). 
About $5-10 \%$ of the parathyroid adenomas, which are the cause of HPT, are ectopic (1). The locations of ectopic parathyroid adenomas are frequently retroesophageal, paraesophageal, mediastinal, intrathymal or in carotid sheath (3).

Surgical success depends largely on the preoperative determination of the gland's localization. Today, various imaging modalities are used in preoperative imaging of parathyroid adenomas. These methods include ultrasound (USG), radionuclide methods such as Tc-99m methoxyisobutylisonitrile (MIBI), Tc-99m tetrofosmin scintigraphy, computed tomography (CT) and magnetic resonance imaging (MRI) (4,5). Ectopic parathyroid adenomas are usually found in the parathymic or thymic tissue at the anterior mediastinum. Cervical USG cannot help in the preoperative locating of these lesions. Today, the radionuclide imaging with $99 \mathrm{mTc}$-sestamibi scan accompanied by single photon emission computed tomography/computed tomography (SPECT/CT) is the most commonly used method for detecting adenomas. USG is also commonly used (6). In cases where the first attempt fails, reoperations increase morbidity because there are adhesions in the tissues. Since the parathyroid scintigraphy can also be used to examine the mediastinum, the accuracy of the scintigraphy in this area is high. In some recent studies it has been show that Technetium $99 \mathrm{~m}$ MIBI parathyroid scintigraphy can be used for the localization of parathyroid pathologies. Kedarisetty et al. (7) state that the sensitivity and specificity of SPECT/CT for parathyroid adenomas are reported to be $77 \%$ and $71 \%$, respectively.

\section{CASE REPORTS}

Seven patients with/without the history of total/subtotal parathyroidectomy operation who underwent SPECT/CT with Tc-99m sestamibi due to high PTH level and who had mediastinal ectopic parathyroid adenomas between January 2015 and September 2018 were included in the study. Five cases were performed video-assisted thoracic surgery (VATS) and the remaining two were videoassisted mediastinoscopy (VAM). The success of the surgery was assessed with preoperative and postoperative PTH levels. All procedures were carried out following the rules of the Declaration of Helsinki. Informed written consents were taken from all patients.

There were six women and one man whose mean age was $52.4 \pm 19.0$ (range, 23-73) years. Preoperative and postoperative serum PTH and calcium values of the cases are given in Table 1. Mediastinal adenomas, ranging from 1.5 to $6 \mathrm{~cm}$ in size, were successfully treated after single attempt. Three of the cases were secondary HPT patients who underwent hemodialysis due to chronic renal failure. There were two cases with thyroid pathology. Surgical complications developed in two cases (1 hoarseness, 1 empyema). Both cases with complications were hemodialysis patients. Persistent hypocalcemia was seen in one of the cases. One of the patients had a history of operation due to parathyroid carcinoma in 2017. This patient's parathyroid adenoma resected with VATS and although the postoperative blood PTH level decreased, the normal PTH levels could not be reached. Some examples of parathyroid adenomas that were detected in SPECT/CT were shown in Figure 1 and 2.

\section{DISCUSSION}

The treatment of PHP was including bilateral neck exploration, identification of all parathyroid glands, and removal of pathologically enlarged glands. Recently, unilateral surgical approach and focal exploration with the help of localization studies have been accepted (8). In a case presented by Fatimi et al. (9), a mediastinal ectopic parathyroid adenoma at the anterior mediastinum was resected with VATS. They also stated that VATS is a safe and effective procedure for the resection of ectopic mediastinal parathyroid adenoma.

Imaging in HPT can be performed by parathyroid scintigraphy (PS), USG, CT and MRI, but the most recommended two methods are PS and USG. However, imaging should not be used to diagnose HPT but to identify the location of the lesion in biochemically proven HPT patients. The only management method for HPT patients is the surgical treatment. As a result of the switch from examination of four parathyroid glands by bilateral neck exploration to minimally invasive surgical procedures, precise location of the lesion prior to surgery has become one of the most important factors in the success of the operation (2). VATS technique can be used for parathyroidectomy and it has some advantages over sternotomy or thoracotomy like short operative time and better visualization of the tumor (10).

We also used Tc-99 MIBI PS, which is recommended for precise localization. USG is inadequate when ectopic adenomas are identified. The location of ectopic parathyroid adenomas is frequently retroesophageal,

Table 1. General characteristics and outcomes of the cases

\begin{tabular}{ccccccccccc}
\hline Case & Age & Gender & $\begin{array}{c}\text { Primary } \\
\text { Disease }\end{array}$ & $\begin{array}{c}\text { Dimension } \\
\text { of ePT }(\mathbf{m m})\end{array}$ & $\begin{array}{c}\text { Surgical } \\
\text { Method }\end{array}$ & $\begin{array}{c}\text { Complication } \\
\text { Preop } \\
\text { PTH }\end{array}$ & $\begin{array}{c}\text { Postop } \\
\text { PTH }\end{array}$ & $\begin{array}{c}\text { Preop } \\
\text { Ca }\end{array}$ & $\begin{array}{c}\text { Postop } \\
\text { Ca }\end{array}$ \\
\hline 1 & 23 & Female & CRF, Hypothyroidism & 15 & VAM & hoarseness & 1350 & 6.5 & 12.20 & 9.60 \\
2 & 39 & Female & CRF & 20 & VAM & - & 1270 & 71.0 & 9.80 & 5.30 \\
3 & 46 & Female & CRF & 22 & VATS & empyema & 2200 & 190 & 8.90 & 5.60 \\
4 & 69 & Female & Hyperthyroidism & 38 & VATS & - & 1650 & 126 & 10.20 & 7.50 \\
5 & 71 & Female & Hyperthyroidism & 65 & VATS & - & 1460 & 92.4 & 12.40 & 8.60 \\
6 & 46 & Male & Hyperparathyroidism & 60 & VATS & - & 259.30 & 1.2 & 10.70 & 10.00 \\
7 & 73 & Female & Hyperparathyroidism & 65 & VATS & - & 953.50 & 86.48 & 12.43 & 8.27 \\
\hline ePT: Ectopic Parathyroid Adenoma, PTH: Parathormone, Ca: Calcium, CRF: Chronic Renal Failure, VAM: Video-assisted Mediastinoscopy, VATS: Video-assisted Thoracic Surgery
\end{tabular}



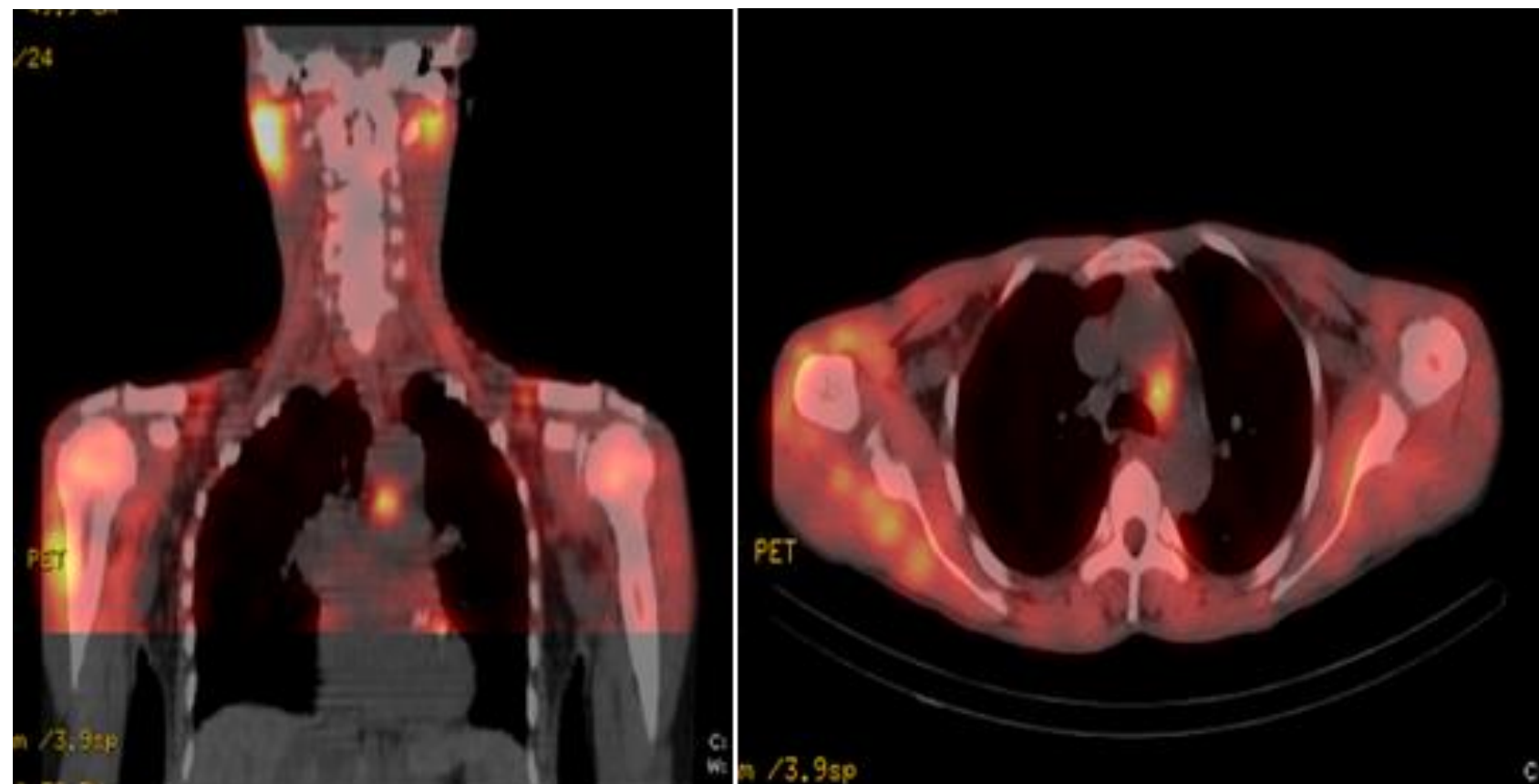

Figure 1. Ectopic parathyroid tissue located in left paratracheal area

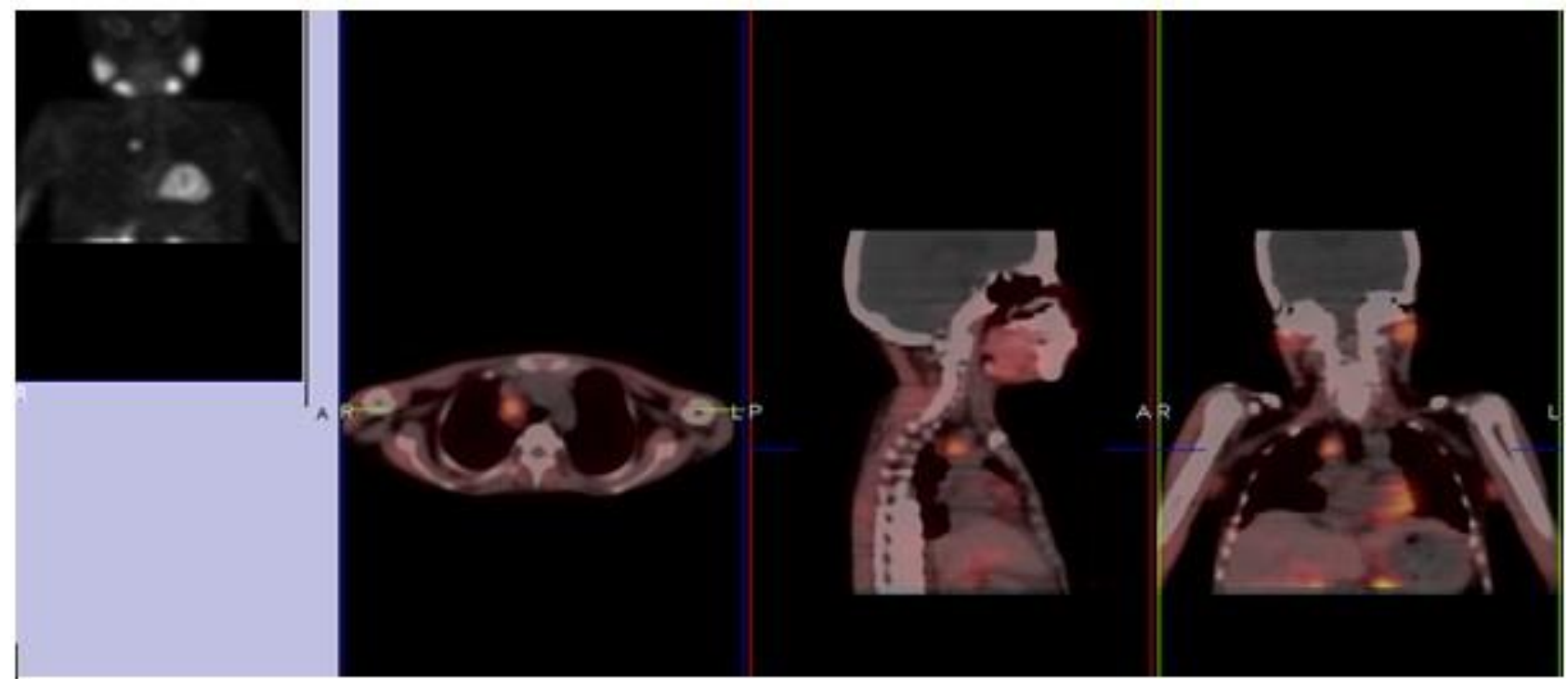

Figure 2. Ectopic parathyroid tissue located in right upper paratracheal area

paraesophageal, mediastinal, intrathymal or in carotid sheath (3). Locations of the cases were lower and upper paratracheal in our study.

Better cosmetic results can be obtained up to $90 \%$ using minimally invasive surgical methods and small incisions in solitary adenomas. In addition, some other advantages have been reported with minimally invasive surgical methods such as; reduction of complications including recurrent nerve damage and postoperative hypocalcemia, shortening of operation and hospitalization time and ensuring earlier healing. Equally successful results to the classical method were achieved by minimally invasive surgical methods $(11,12)$. Lihara et al. (13) presented 8 cases with parathyroid adenomas that were applied VATS and no complication were seen in any patient. Hoarseness developed in 1 case, and postoperative hypocalcemia developed in 2 cases as postoperative complications in our series; both of the cases with hypocalcemia were hemodialysis patients due to chronic renal failure.

The most important factor affecting the success of minimally invasive surgery is the correct location of the lesion (14). We also detected the location correctly with Tc-99 m MIBI PS in 6 cases. We think that Tc-99m MIBI is safe for lesion detection.

If the mediastinal ectopic parathyroid adenoma is fully localized before surgery, it can be treated with minimally invasive surgical methods. Especially in the case of secondary HPT, the risk of surgical complications is high. 


\section{REFERENCES}

1. Sarıcı İŞ, Kılıç B, Doğan S, Tanju S, Çaynak M, Ağcaoğlu O, et al. Surgical resection of ectopic parathyroid adenoma by sternotomy. Journal of Dialog in Endocrinology. 2012:9(3):140-4.

2. Erdil TY, Uslu Beşli L. Clinical value of single photon emission computed tomography/computed tomography in the evaluation of Tc-99m MIBI parathyroid scintigraphy. Nucl Med Semin. 2016:2(1):49-56.

3. Kim YS, Kim J, Shin S, Thoracoscopic removal of ectopic mediastinal parathyroid adenoma. Korean J Thorac Cardiovasc Surg. 2014:47(3):317-9.

4. Khafif A, Masalha M, Landsberg R, Domachevsky L, Bernstine H, Groshar D, et al. The role of F18fluorocholine positron emission tomography/magnetic resonance imaging in localizing parathyroid adenomas. Eur Arch Otorhinolaryngol. 2019:276(5):1509-16.

5. Beheshti M, Hehenwarter L, Paymani Z, Rendl G, Imamovic L, Rettenbacher R, et al. 18F-Fluorocholine $\mathrm{PET} / \mathrm{CT}$ in the assessment of primary hyperparathyroidism compared with $99 \mathrm{mTc}$-MIBI or 99mTc-tetrofosmin SPECT/CT: a prospective dualcentre study in 100 patients. Eur J Nucl Med Mol Imaging. 2018:45(10):1762-71.

6. Bilezikian JP, Brandi ML, Eastell R, Silverberg SJ, Udelsman R, Marcocci C, et al. Guidelines for the management of asymptomatic primary hyperparathyroidism: summary statement from the Fourth International Workshop. J Clin Endocrinol Metab. 2014:99(10):3561-9.

7. Kedarisetty S, Fundakowski C, Ramakrishnan K, Dadparvar S. Clinical value of Tc99m-MIBI SPECT/CT versus 4D-CT or US in management of patients with hyperparathyroidism. Ear Nose Throat J. 2019:98(3):149-57.

8. Korukluoğlu B, Kıyak G, Çelik A, Uçar AE, Ergül E, Kuşdemir A. Our surgical approach to parathyroid adenoma and the role of localization studies. Turkiye Klinikleri J Med Sci. 2008:28(1):24-9.

9. Fatimi SH, Inam H, Chagan FK, Choudry UK. Management of mediastinal parathyroid adenoma via minimally invasive thoracoscopic surgery: Case report. Int J Surg Case Rep. 2017:40(1):120-3.

10. Naik D, Jebasingh KF, Ramprasath, Roy GB, Paul MJ. Video assisted thoracoscopic surgery (VATS) for excision of an ectopic anterior mediastinal intra-thymic parathyroid adenoma. J Clin Diagn Res. 2016:10(6):PD22-4.

11. Taubman ML, Goldfarb M, Lew JI. Role of SPECT and SPECT/CT in the surgical treatment of primary hyperparathyroidism. Int $\mathbf{J}$ Mol Imaging. 2011;2011:141593.

12. Grant CS, Thompson G, Farley D, van Heerden J. Primary hyperparathyroidism surgical management since the introduction of minimally invasive parathyroidectorny: Mayo Clinic experience. Arch Surg. 2005:140(5):472-9.

13. Iihara M, Suzuki R, Kawamata A, Horiuchi K, Okamoto T. Thoracoscopic removal of mediastinal parathyroid lesions: selection of surgical approach and pitfalls of preoperative and intraoperative localization. World J Surg. 2012:36(6):1327-34.

14. Bagul A, Patel HP, Chadwick D, Harrison BJ, Balasubramanian SP. Primary hyperparathyroidism: An analysis of failure of parathyroidectomy. World $\mathbf{J}$ Surg. 2014:38(3):534-41. 